\title{
Framework of guest focused among resorts in Cagayan Valley Region, Philippines
}

Mones, Jehoana

Isabela State University - Cauayan, Philippines (jehoanamones@yahoo.com)

Borbon, Noelah Mae D. $\bowtie$

Lyceum of the Philippines University Batangas, Philippines (nmdborbon@lpubatangas.edu.ph)

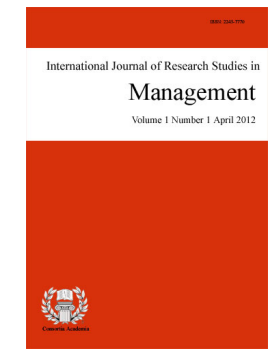

ISSN: $2243-7770$ Online ISSN: 2243-7789

OPEN ACCESS

\section{Abstract}

This study aims to proposed a framework of guest focused among resorts in Cagayan Valley Region, how does the new operation most likely be change or upgrade for new normal operations in the region, amidst the abrupt change of economy, to analyze the operating procedure for a new normal in the hospitality industry. The nature of the tourism industry such as resort, allows business to operate in to remote areas. Economically, tourism provides employment and wages that help to decrease unemployment and increase the circulation of money through the community. Thus, tourism specifically investing a resort means money for capital investment and local tax revenues. Tourist for example take with them their own peculiar tastes and standard of living, to which the investor must cater if expects, repeated business. In developing countries, the need to accommodate these special requirements often results the need for imported capital, imported technology or even imported management skills. Thus, some investors, as an opportunity, seek for incentives in local projects such as team building facilities designed to serve inbound visitor. Once built, the facilities become indispensable as economic asset. Quantitative method is the type of research in the study, participants of the data gathered was the customer, the owner and the LGU of Region. The quality of the service serves within the region on how to cope up in the new normal comparison of services before during and new normal due to pandemic. Sudden changes in hospitality decline the economic grow worldwide, thus in whatever circumstances a future plan was ahead of time, a lesson to learned that nobody knows it will happen, the researcher would like to recommend the region in partnership with LGU to work together to start fresh to encourage customers the safes way in general.

Keywords: consumer buying behavior, loyalty, service quality, resort 


\section{Framework of guest focused among resorts in Cagayan Valley Region, Philippines}

\section{Introduction}

A resort is a place with a lot of special amenities for rest, relaxation, and entertainment. Resorts are designed to attract a wide range of vacationers and encourage tourism. It might be a location, a community, or a business that is owned and operated by anyone who fits certain criteria. When it comes to hotels or resorts, guests that choose to stay at one hotel or resort over another are termed loyal. preferring a certain hotel or resort brand over others. Calculating a guest's lifetime worth to the hotel/resort or brand is a part of assessing how far to go to earn their loyalty. Valuing guest loyalty through services provided by the owner aside from the resort's location is maintaining quality and developing more through innovation and advancement of technology, which will aid a marketing strategy to encourage more people to visit the site, which is not just fiction but reality.

Tourist experiences are so devoured not just while on vacation, but also subsequently by recreating them as stories, which allows the tourist to make sense of the events he witnessed (Carringan et al., 2017). Furthermore, timeliness expectations differ depending on the kind of complaint (reservations, accommodations, billing, and service), allowing for better management of timeliness difficulties when resolving complaints (Istanbulluoglu, 2017). According to Wang et al. (2017) the use of cellphones in the tourism sector is a relatively new phenomenon. Past researches have validated the importance of customer satisfaction, service quality and value as prerequisites of customer loyalty formation (Mohammed et al., 2015).

According to Godovykh, and Tasci (2020), there is a range of attitudes by which tourist behavior and end satisfaction can be impacted and determined in the general marketing literature review. According to $\mathrm{Wu},(2016)$, emotional assessments of a product or destination are considered attitudes toward a product or destination since they are linked in the consumer's mind to affective connections such as positive, neutral, or negative sentiments. Furthermore, while studies have looked into people's perceptions of climate change and its relevance to tourism, they have mostly focused on people in wealthy countries. Following economic progress, much future tourism growth will come from developing countries, often in areas where climate change will be felt severely.

Prior study into the elements that matter to resort visitors has tended to focus on a certain resort setting or market segment, which has resulted in a bias toward that setting or segment. factors relating to an activity While this emphasis on activity-related features is beneficial, it has hampered our knowledge of the relevance of the nonactivity, hospitality-based elements found in all resort types. The goal of this study is to fill a vacuum in the research literature by gaining a deeper knowledge of the value of these conventional hospitality aspects to resort customers. Three underlying variables are discovered using survey data acquired from a sample of recent resort guests.

\subsection{Objective of the Study}

This study aims to propose a framework of Guest Focused among Resorts in Cagayan Valley Region, Philippines. More specifically, this study aims to assess guest satisfaction, factors that influence guest loyalty to resorts and consumer buying; and to test the significant relationship between guest satisfaction, loyalty, and consumer buying behavior

\section{Methods}

The data in this study was presented using a descriptive technique. Descriptive research is a sort of study in which data is acquired without any manipulation. In other terms, it is a non-experimental study. It provides answers to the following questions: who, what, when, and where. Descriptive research is conducted to merely identify or describe what is. This form of study involves just observing a scenario and drawing conclusions from 
it. This is done by watching a specific behavior for a period of time.

The majority of the respondents on this study are in the middle ages bracket $* 18-26$ with an average of 36.5 percent, are just fresh graduates and some are continuing to visit the place as well as the quality of services that have been offered to them, and some are international to visit the place, the majority of the respondents on this study are in the middle ages bracket $* 18-26$ with an average of 36.5 percent, are just fresh graduates and some are continuing to visit the place and quality of services that have been offered to participate in the study.

According to statistics provided by the Department of Tourism 2020, the study's respondents were guests from Isabela's top ten most frequented resorts. A sample size of 405 was used from a total of 17,758 as of Accommodation establishment arrivals 2020, based on the Raosoft Calculator, which has a 5\% margin of error and a $95 \%$ confidence level (1st quarter). Isabela, Quirino, Cagayan, Nueva Vizcaya, and Batanes will have an equal distribution of 75 people in each province in Cagayan region 2, which comprises Isabela, Quirino, Cagayan, Nueva Vizcaya, and Batanes.

An Adopted instrument was used. Instruments for gathering data to collect data for the study and research of Bathan et al. (2017) entitled "Consumer Buying Behavior among Resort's Guests in Batangas Province," the researcher used an adopted questionnaire derived from De Guzman et al. (2020) entitled "Guest Satisfaction and Loyalty among Beach Resorts in Laiya, Batangas. This has been modified and undergone into content validation and pilot testing to ensure the validity and reliability of the instrument. The Cronbach alpha value for: Guest Satisfaction (0.941); Guest Loyalty (0.899); Consumers Buying Behavior (0.930) denotes that the instrument is excellent to use based on the rule of thumb.

\section{Result and Discussion}

As seen in table 1, the assessment on Guest Satisfaction, Factors Affecting Guest Loyalty, and Consumer Buying Behavior were evaluated by the respondents as satisfied, often affected by the enumerated factors and the respondents agreed being affected by the enumerated factors of consumer buying behavior.

\section{Table 1}

Assessment on guest satisfaction, guest loyalty factors, and consumer purchasing behavior

\begin{tabular}{|c|c|c|c|c|}
\hline Guest Satisfaction & Composite Mean & Standard Deviation & Verbal Interpretation & Rank \\
\hline Timeliness & 3.22 & 0.44 & Satisfied & 6 \\
\hline Completeness & 3.20 & 0.29 & Satisfied & 7 \\
\hline Courtesy & 3.24 & 0.32 & Satisfied & 4 \\
\hline Consistency & 3.25 & 0.31 & Satisfied & 2.5 \\
\hline Accessibility & 3.31 & 0.31 & Satisfied & 1 \\
\hline Accuracy & 3.25 & 0.31 & Satisfied & 2.5 \\
\hline Responsiveness & 3.23 & 0.31 & Satisfied & 5 \\
\hline \multicolumn{5}{|c|}{ Factors Affecting Guest Loyalty } \\
\hline Convenience & 3.24 & 0.32 & Often & 4 \\
\hline Expectation & 3.26 & 0.34 & Often & 2 \\
\hline Customer Service & 3.26 & 0.36 & Often & 2 \\
\hline Personal Relationships & 3.26 & 0.35 & Often & 2 \\
\hline Rewards & 3.10 & 0.48 & Often & 5 \\
\hline \multicolumn{5}{|c|}{ Consumer Buying Behavior } \\
\hline Cultural Factors & 3.47 & 0.39 & Agree & 1 \\
\hline Social Factor & 3.38 & 0.35 & Agree & 2 \\
\hline Personal Factor & 3.34 & 0.43 & Agree & 4 \\
\hline Psychological Factor & 3.37 & 0.31 & Agree & 3 \\
\hline
\end{tabular}

Scale: 3.50-4.00: Very Satisfied (VS); 2.50-3.49: Satisfied (S); 1.50-2.49: Dissatisfied (DS); 0.50-1.49: Very Dissatisfied (VD)

Scale 3.50-4.00: Always (A); 2.50-3.49: Often (O); 1.50-2.49: Sometimes (S); 0.50-1.49: Never(N)

Scale: 3.50-4.00: Strongly Agree (SA); 2.50-3.49: Agree (A); 1.50-2.49: Disagree (D); 0.50-1.49: Strongly Disagree (SD)

In terms of guest satisfaction, accessibility is at the top of the list (3.31). Attractions, airports, universities, 
and public transportation, as well as green areas, bodies of water, and local businesses, are all important factors to consider when buying a home. In this regard, complimentary parking and airport shuttle bus service may help to mitigate the disadvantages of poor airport connectivity. Furthermore, diverse hotel location satisfaction impacts are mentioned in online reviews based on tourists' experiences and travel habits. Tourists are most likely traveling destination by destination since smartphone applications such as Waze, Google Maps, Grab, and others make it easier to access or learn the location of a given area and how to get there (Yang et al., 2018).

Consistency and accuracy (3.25) were ranked last. Quality consistency is vital for acquiring new clients, strengthening brand reputation, lowering expenses, and improving business efficiency. Nonetheless, difficulties in establishing and implementing service quality measures are typically linked to service consistency issues (Herath et al., 2019). This technique is aimed to promote the service consistency of establishment services by including customer loyalty and customer expectations of service quality. According to Kadlubek's (2020) research, the component of their reliability is completeness, which is supplemented by correctness and timeliness of services. If at least one item is missing from the order being processed, the service is considered incomplete. Failure to meet expectations in terms of service completeness leads to deliveries. Completeness may receive a high rating to support the study, but it is still ranked last because it is not seen or felt by the majority of clients. Completeness (3.20) and punctuality (3.22) are the least vocally understood as satisfied.

With a score of 3.31, accessibility comes out on top in terms of guest pleasure. Accessibility in a specific resort is also an important issue to consider because the customer has a concept for the site to be and have simple access, and it is also a truth that the consumer would recommend that accessible region in one way or another.

Expectation, customer service, and personal relationships (3.26) are at the top of the list of elements determining client loyalty, as those signs are verbally understood as often as stated by as those indicators are indeed well-practiced by the staffs of a given institution. They are able to fulfill or even exceed their clients' expectations by providing excellent customer service whenever they are in need of assistance, and they approach them in such a way that the customers feel important in the way the staff accommodates them. Undoubtedly, the service quality provided is vital to the hotel's performance, according to Liat et al. (2017). As a result, any service deficiency must be handled appropriately to preserve a high level of client satisfaction and the hotel's reputation. As a result, it's critical that service recovery plans are properly developed to address the various sorts of service failures that can occur. Expectations, customer service, and personal relationships are at the top of the list; these three are very vital to think about because the resort and the consumer have an instant interaction. A category that encompasses all of the services supplied to a consumer during their stay.

Convenience (3.24) and incentives (3.10) are the least frequently verbally understood. It may be considered one of the least important indications for establishments because some do not provide prizes such as discounts, freebies, or trial amenities for loyal and first-time clients, or have any incentives in comparison to others. The Customer Incentive System is designed to build an efficient demand response program in order to enhance demand elasticity (Vu et al., 2018).

Cultural elements (3.47), and social variables (3.38) vocally expressed as agree, are at the top of the list when it comes to customer buying behavior. Individualism and collectivism theory, in particular, contains significant insights into consumer behavior that might aid us in gaining a better and more thorough knowledge of the phenomenon of impulsive purchasing (Auf et al., 2018). This is in line with earlier studies that show cultural influences have a significant impact on consumers' impulsive purchasing behavior.

Psychological variables (3.37) and personal aspects (3.34), on the other hand, are verbally regarded as agreeing the least. Because of their psychological approach and personal insights into the products or services, consumers or purchasers tend to buy impulsively. Consumers' self-control and mood states mediate and define the affective and cognitive psychological systems involved in impulse purchases. By describing these routes and processes, this study aids in explaining the causes that contribute to impulse purchases and the function of factors in resisting such impulses. In previous studies, it also describes inconsistent results by emphasizing the 
context-dependence of distinct drivers, according to Lyer et al. (2020). The results of a moderator study, in particular, reveal that the impacts of various variables are dependent on the context of use (e.g., the identity expression of the commodity, industry price level).

Table 2

Relationship between guest satisfaction and loyalty and consumer purchasing behavior factors

\begin{tabular}{|c|c|c|c|c|c|c|c|c|}
\hline \multirow{2}{*}{\multicolumn{2}{|c|}{ Factors affecting Loyalty }} & \multicolumn{7}{|c|}{ Guest Satisfaction } \\
\hline & & Time & Comp & Cour & Cons & Acce & Accu & Resp \\
\hline \multirow[t]{2}{*}{ Convenience } & r-value & $.258(* *)$ & $.384(* *)$ & $.440(* *)$ & $.461(* *)$ & $.383(* *)$ & $.427(* *)$ & $.520(* *)$ \\
\hline & $p$-value & .000 & .000 & .000 & .000 & .000 & .000 & .000 \\
\hline \multirow[t]{2}{*}{ Expectation } & r-value & $.206(* *)$ & $.348(* *)$ & $.336(* *)$ & $.409(* *)$ & $.300(* *)$ & $.386(* *)$ & $.379(* *)$ \\
\hline & $p$-value & .000 & .000 & .000 & .000 & .000 & .000 & .000 \\
\hline \multirow[t]{2}{*}{ Customer Service } & r-value & $.207(* *)$ & $.358(* *)$ & $.362(* *)$ & $.431(* *)$ & $.305(* *)$ & $.398(* *)$ & $.451(* *)$ \\
\hline & $p$-value & .000 & .000 & .000 & .000 & .000 & .000 & .000 \\
\hline \multirow{2}{*}{$\begin{array}{l}\text { Personal } \\
\text { Relationships }\end{array}$} & r-value & $.165(* *)$ & $.325(* *)$ & $.347(* *)$ & $.349(* *)$ & $.265(* *)$ & $.359(* *)$ & $.403(* *)$ \\
\hline & $p$-value & .001 & .000 & .000 & .000 & .000 & .000 & .000 \\
\hline \multirow[t]{2}{*}{ Rewards } & r-value & $.242(* *)$ & $.365(* *)$ & $.291(* *)$ & $.379(* *)$ & $.145(* *)$ & $.394(* *)$ & $.355(* *)$ \\
\hline & $p$-value & .000 & .000 & .000 & .000 & .003 & .000 & .000 \\
\hline \multirow{2}{*}{\multicolumn{2}{|c|}{ Consumer Buying Behavior }} & \multicolumn{7}{|c|}{ Guest Satisfaction } \\
\hline & & Time & Comp & Cour & Cons & Acce & Accu & Resp \\
\hline \multirow[t]{2}{*}{ Cultural } & r-value & $.116(*)$ & $.264(* *)$ & $.267(* *)$ & $.251(* *)$ & $.114(*)$ & $.298(* *)$ & $.329(* *)$ \\
\hline & $p$-value & .020 & .000 & .000 & .000 & .021 & .000 & .000 \\
\hline \multirow[t]{2}{*}{ Social } & r-value & $.176(* *)$ & $.297(* *)$ & $.296(* *)$ & $.303(* *)$ & $.189(* *)$ & $.377(* *)$ & $.357(* *)$ \\
\hline & $p$-value & .000 & .000 & .000 & .000 & .000 & .000 & .000 \\
\hline \multirow[t]{2}{*}{ Personal } & r-value & $.124(*)$ & $.263(* *)$ & $.259(* *)$ & $.288(* *)$ & .074 & $.406(* *)$ & $.319(* *)$ \\
\hline & $p$-value & .013 & .000 & .000 & .000 & .136 & .000 & .000 \\
\hline \multirow[t]{2}{*}{ Psychological } & r-value & $.124(*)$ & $.262(* *)$ & $.269(* *)$ & $.293(* *)$ & $.173(* *)$ & $.277(* *)$ & $.383(* *)$ \\
\hline & $p$-value & .012 & .000 & .000 & .000 & .000 & .000 & .000 \\
\hline \multirow{2}{*}{\multicolumn{2}{|c|}{ Consumer Buying Behavior }} & \multicolumn{7}{|c|}{ Factors Affecting Loyalty } \\
\hline & & Conv & & Expe & Cust & Pers & Rewa & \\
\hline \multirow[t]{2}{*}{ Cultural } & r-value & $.280(* *)$ & & $.293(* *)$ & $.325(* *)$ & $.322(* *)$ & $.369(* *)$ & \\
\hline & $p$-value & .000 & & .000 & .000 & .000 & .000 & \\
\hline \multirow[t]{2}{*}{ Social } & r-value & $.275(* *)$ & & $.389(* *)$ & $.276(* *)$ & $.252(* *)$ & $.454(* *)$ & \\
\hline & $p$-value & .000 & & .000 & .000 & .000 & .000 & \\
\hline \multirow[t]{2}{*}{ Personal } & r-value & $.300(* *)$ & & $.343(* *)$ & $.264(* *)$ & $.234(* *)$ & $.572(* *)$ & \\
\hline & $p$-value & .000 & & .000 & .000 & .000 & .000 & \\
\hline \multirow[t]{2}{*}{ Psychological } & r-value & $.329(* *)$ & & $.358(* *)$ & $.308(* *)$ & $.343(* *)$ & $.385(* *)$ & \\
\hline & $p$-value & .000 & & .000 & .000 & .000 & .000 & \\
\hline
\end{tabular}

Note: **Highly Significant at $\mathrm{p}<0.01 ; *$ Significant at $\mathrm{p}<.05$ (two-tailed)

Timeliness (Time) Completeness (Comp) Courtesy (Cour) Consistency (Cons) Accessibility (Acce) Accuracy (Accu) Responsiveness (Resp) Convenience (Conv) Expectation (Expe) Customer Service (Cust) Personal Relationship (Pers) Rewards (Rewa)

The Relationship of Guest Satisfaction, Factors Affecting Loyalty and Consumer Buying Behavior is shown in Table 2. As indicated by computed p-values less than 0.05 alpha level, there is a substantial moderate positive link between guest satisfaction and elements affecting loyalty and customer buying behavior. If a customer is loyal, the industry should focus on these relationships because it ensures that the customer will return. This suggests that those who are more satisfied with their guests are also more content with their fidelity and purchasing habits. Customer loyalty is crucial in the hospitality industry since it strengthens the relationship between the guest and the resort. This simply goes to show how crucial client loyalty is to a customer's or guest's purchasing behavior.

This is comparable to Hassan et al. (2017)'s study, which found that brand loyalty influences customer behavior. As a result, it is critical for independent firms to develop marks that can compete with the large marked items on store shelves. Building and maintaining good guest connections is also vital for the success of a modern hotel, especially for small hotels that do not have full access to continual technology improvements and large marketing budgets (Net Affinity, 2016). 
Mones, J., \& Borbon, N. M. D.

With a $p$-value of .003 , the prize has the lowest ranking, implying that they did not obtain enough reward or satisfaction. Receiving a reward will demonstrate your hard effort. Employees have been observed to perceive cultural identity as more advanced than transactional reward power as a result of performance management, although interpersonal tangible benefits have caused employees to perceive culture as more goal-oriented than innovation (Xenikou, 2017). When customers are ready to feel satisfied with the goods and services they receive, they will feel knowledgeable about the company, which will lead to loyalty. Furthermore, according to Nobar and Rostamzadeh (2018), customer pleasure is critical to client loyalty. The ultimate goal of gaining customer loyalty is to ensure that the customer is always satisfied with their preferences and expected services.

With a $p$-value of .012 for the psychological element, it came out on top. Consumers make purchasing decisions every day. When people choose a product, they consider if it will meet a need. A desire can be stimulated to an acceptable degree of severity when it alters a purpose. A motive is essentially a need that pushes a person to seek fulfillment. With a $p$-value of .013 , the personal category has the lowest ranking in consumer buying behavior, and each customer has a unique personality and buying preferences. The emotional and behavioral cognitive aspects associated to impulse purchases are expressed and illustrated by customers' self-control and emotions. The entire study helps to understand variables that link to impulse purchases and the position of variables in attempting to resist such cravings by creating these paths and operations (Iyer et al., 2020). The estimated p-values of less than 0.05 alpha level indicate a substantial moderate positive association between consumer buying behavior and factors impacting loyalty. This means that individuals who responded well to consumer buying behavior also responded positively to the factors determining their loyalty.

The relationship between guest loyalty and increased buying behavior is that both have a good point in the guest loyalty on impulsive buying awareness and personal reviews to turn into a positive effect on suggestion that will result in rewarding. Customer purchasing behavior has a significant impact on the responsibilities of the corporation's middleman. It demonstrates that a customer's positive attitude toward corporate responsibility has a direct and positive impact on their purchasing behavior. Individuals are rewarded for their actions not only because they have received positive results directly (e.g., in the form of food or money), but also because they have been observed by others. Even this phenomenon, known as vicarious pleasure, is a persistent source of fascination for psychologists and economists (Vahdati et al., 2015).

Table 3

Consumer purchasing behavior model summary

\begin{tabular}{|c|c|c|c|c|}
\hline Model & $\mathrm{R}$ & R Square & Adjusted R Square & Std. Error of the Estimate \\
\hline \multicolumn{5}{|c|}{ Cultural Aspect } \\
\hline 1 & .369 (a) & .136 & .134 & .36323 \\
\hline 2 & $.426(\mathrm{~b})$ & .181 & .177 & .35409 \\
\hline 3 & $.450(\mathrm{c})$ & .202 & .196 & .34998 \\
\hline \multicolumn{5}{|c|}{ Social Aspect } \\
\hline 1 & $.454(a)$ & .206 & .204 & .30824 \\
\hline 2 & $.503(\mathrm{~b})$ & .253 & .249 & .29943 \\
\hline 3 & $.522(\mathrm{c})$ & .272 & .267 & .29592 \\
\hline 4 & $.530(\mathrm{~d})$ & .280 & .273 & .29457 \\
\hline \multicolumn{5}{|c|}{ Personal Aspect } \\
\hline 1 & $.572(a)$ & .327 & .326 & .35189 \\
\hline 2 & $.605(b)$ & .366 & .363 & .34206 \\
\hline 3 & $.614(\mathrm{c})$ & .378 & .373 & .33935 \\
\hline \multicolumn{5}{|c|}{ Psychological Aspect } \\
\hline 1 & $.385(\mathrm{a})$ & .148 & .146 & .28423 \\
\hline 2 & $.466(\mathrm{~b})$ & .217 & .213 & .27273 \\
\hline 3 & $.488(\mathrm{c})$ & .238 & .233 & .26939 \\
\hline $\begin{array}{l}\text { a. Predictor } \\
\text { b. Predictor } \\
\text { c. Predictor } \\
\text { d. Depende }\end{array}$ & $\begin{array}{l}\text { Constant), F } \\
\text { Constant), F } \\
\text { Constant), F } \\
\text { Variable: cu }\end{array}$ & $\begin{array}{l}\text { ve } \\
\text { ve, ResAve } \\
\text { ve, ResAve, Pers } \\
\text { socia, personal, }\end{array}$ & logical & \\
\hline
\end{tabular}

86 Consortia Academia Publishing (A Partner of Tourism Educators and Movers of the Philippines) 
Model 3 has the best model fit for consumer buying behavior, as indicated by the computed R-value of 0.450 (c), which is a moderate positive correlation with a computed r-square of 0.202 , indicating that the cultural aspect can be explained by the 20.2 percent combined scores of Responsiveness from customer satisfaction, while Rewards and personal relationships can be explained by the 20.2 percent combined scores of Rewards and personal relationships. Model 4 has the best model fit for consumer buying behavior, as evidenced by the computed R-value of $.530(\mathrm{~d})$, which is a moderate positive correlation with a computed r-square of.280, indicating that the social aspect can be explained by the 28 percent combined scores of responsiveness and accuracy from customer satisfaction, while rewards and expectations from.

Model 3 has the best model fit for consumer buying behavior, as indicated by the computed R-value of .614(d), which has a strong positive correlation with a computed r-square of 0.378 , which means that the personal aspect can be explained by the $37.8 \%$ combined scores of accessibility and accuracy from customer satisfaction, while rewards from factors. Model 3 has the best model fit for consumer buying behavior, as indicated by the computed R-value of 0.488 (c), which has considered moderate positive correlation with computed r-square of 0.238 , which means that the personal aspect can be explained by the 23.8 percent combined scores of responsiveness from customer satisfaction, while rewards and personal relation can be explained by the 23.8 percent combined scores of responsiveness from customer satisfaction. According to a study by Xiang et al. (2016), when people buy things after seeing them and then suddenly realizing they need them, the phenomenon is clarified. This type of buying behavior is known as reminder impulsive buying, and it's comparable to the reminder in which shoppers buy products when they first see them. What distinguishes the two behaviors is that buying suggestions occurs when buyers have no prior knowledge of the goods and spontaneously picture a need for it after seeing it.

In terms of services, the region has a lot to offer, and I must add that positive reactions lead to positive outcomes. Filipinos are truly hospitable in terms of the services we provide, a strategy that has resulted in the majority of resorts in the region being accommodating and sensitive to customer needs, and if promoted, greater revenue would aid the region's economic progress. The researcher created this framework based on the Model summary, which shows the close link between the three variables. As indicated in the framework, customer satisfaction is influenced by psychological, cultural, and social variables, while rewards and personal ties from aspects affecting loyalty are likewise influenced by psychological, cultural, and social factors.

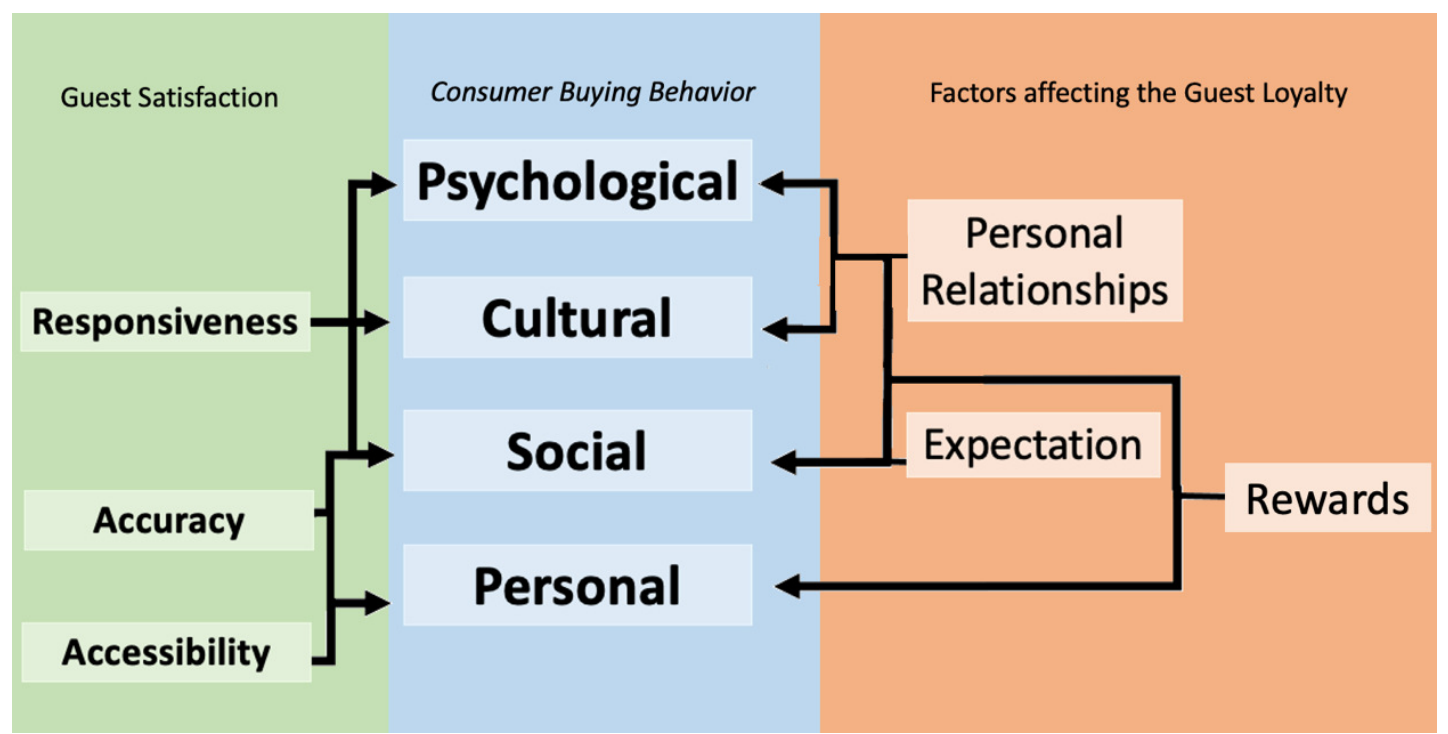

Figure 1. Proposed Framework of Guest Focused

Personal relationships, on the other hand, are one of the most significant parts of loyalty since excellent 
customer interactions can lead to loyal customers and great word of mouth. Tao teaches that (2015), Customer relationship management is a new strategy mechanism aimed at improving business and consumer relationships. Customers are a vital resource for middle-market businesses, and meeting their needs requires the development of customer support and in-depth analysis of the client, so that businesses can maximize client satisfaction and loyalty, and establish mutually beneficial relationships. The higher the client's level of satisfaction, the more likely they are to return. Furthermore, while personal and social factors influence customer satisfaction through accessibility and accuracy, personal relationships, rewards, and expectations from factors driving loyalty are also influenced by personal and social factors through consumer buying behavior. Because of their psychological approach and personal insights into the products or services, consumers or purchasers tend to buy impulsively.

The figure mostly reflects the customer's commitment to the resort; it is a service that works both ways. A positive relationship between the consumer and the resort owner yields a better outcome in terms of the services that the resort has to offer; if the customer is satisfied, it will undoubtedly result in positive reactions from others. According to Liat et al. (2017), the service quality provided is unquestionably important to the resort's success. As a result, any service deficiency must be handled appropriately in order to preserve a high level of guest satisfaction and the resort's reputation. As a result, it's critical that service recovery plans are properly developed to address the various sorts of service failures that can occur.

\section{Conclusion and Recommendation}

The assessment on guest satisfaction reveals that guests are happiest with accessibility and least happy with consistency and accuracy, Expectations, customer service, and personal relationships have the most impact on guests, while convenience and rewards have the least impact. Cultural and social elements are the most prominent influences on consumer purchasing behavior. There is a moderately favorable association between elements affecting loyalty and customer purchasing behavior and visitor satisfaction. For the resort industry in the Region, the researcher was able to proposed a guest focused framework.

Based on the result, it is recommended for the resort management may provide frequent training, learning, and development for their employees to guarantee that all employees deliver correct and consistent service in accordance with the resort's standard operating procedure. Since consumer buying behavior and visitor loyalty have been severely impacted by the pandemic, the resort may consider redesigning their guest acceptance procedure. An online platform or other services may be supplied to ensure client satisfaction. The resort, in collaboration with the local tourism bureau, may cultivate the resort's cultural and social marketing, as well as tourism in general. Future researchers may undertake a similar study on tourist intention to visit and resort business issues in the face of the pandemic.

\section{References}

Auf, M. A. A., Meddour, H., Saoula, O., \& Majid, A. H. A. (2018). Consumer buying behaviour: the roles of price, motivation, perceived culture importance, and religious orientation. Journal of Business and Retail Management Research, 12(4). https://doi.org/10.24052/JBRMR/V12IS04/ART-18

Bathan, A. C. L., Ababao, A. C. J., Christian, J. E. A. B. B., Marquez, N., Resma, R. A. S., Reyes, J. M. M., \& Felicen, S. S. (2017). Consumer buying behavior among resort's guests in Batangas Province. Asia Pacific Journal of Multidisciplinary Research, 5(4).

Carrigan, M., Lazell, J., Bosangit, C., \& Magrizos, S. (2017). Burgers for tourists who give a damn! Driving disruptive social change upstream and downstream in the tourist food supply chain. Journal of Sustainable Tourism, 25(11), 1563-1582. https://doi.org/10.1080/09669582.2017.1291652

De Guzman, J. C. D., Abanilla, J. G. R., \& Abarquez, K. E. L. (2020). Guest Satisfaction and Loyalty among Beach Resorts in Laiya, Batangas. Journal of Tourism and Hospitality Research, 17(1).

Godovykh, M., \& Tasci, A. D. (2020). Satisfaction vs experienced utility: current issues and opportunities. Current Issues in Tourism, 23(18), 2273-2282.

88 Consortia Academia Publishing (A Partner of Tourism Educators and Movers of the Philippines) 
Framework of guest focused among resorts in Cagayan Valley Region, Philippines https://doi.org/10.1080/13683500.2020.1769573

Hassan, M. M., \& Rasel, M. K. A. (2018). Determinants of brand loyalty of millennial or generation Y. Barishal University Journal (PART-3) A Journal of Business Studies, 5(3), 95.

Herath, A. G. T. L., Mallawaarachchi, H., \& Rathnayake, R. M. D. I. M. (2019). Service consistency improvement of facilities management service providing organisations in Sri Lanka. https://doi.org/10.31705/WCS.2019.51

Istanbulluoglu, D. (2017). Complaint handling on social media: The impact of multiple response times on consumer satisfaction. Computers in Human Behavior, 74, 72-82.

Iyer, G. R., Blut, M., Xiao, S. H., \& Grewal, D. (2020). Impulse buying: a meta-analytic review. Journal of the Academy of Marketing Science, 48(3), 384-404. https://doi.org/10.1007/s11747-019-00670-w

Kadłubek, M. (2020). Completeness meter in logistics service quality management of transport companies. International Journal for Quality Research, 14(4). https://doi.org/10.24874/IJQR14.04-15

Liat, C. B., Mansori, S., Chuan, G. C., \& Imrie, B. C. (2017). Hotel service recovery and service quality: Influences of corporate image and generational differences in the relationship between customer satisfaction and loyalty. Journal of Global Marketing, 30(1), 42-51. https://doi.org/10.1080/08911762.2016.1262932

Mohammed Shobri, N. D., \& Putit, L. (2015). Building guest loyalty: The role of guest based brand equity and guest experience in resort hotel industry. Advanced Science Letters, 21(5), 1605-1609. https://doi.org/10.1166/asl.2015.6116

Net Affinity. (2016, April 26). Build a strong relationship with guests: Your hotel's road to profit. Net Affinity https://blog.netaffinity.com

Nobar, H. B. K., \& Rostamzadeh, R. (2018). The impact of customer satisfaction, customer experience and customer loyalty on brand power: empirical evidence from hotel industry. Journal of Business Economics and Management, 19(2), 417-430. https://doi.org/10.3846/jbem.2018.5678

Tao, F. (2015). Customer relationship management based on increasing customer satisfaction. International Journal of Business and Social Science, 5(5).

Vahdati, H., Mousavi, N., \& Tajik, Z. M. (2015). The study of consumer perception on corporate social responsibility towards consumers attitude and purchase behavior. Asian Economic and Financial Review, 5(5), 831-845. https://doi.org/10.18488/journal.aefr/2015.5.5/102.5.831.845

Vu, D. H., Muttaqi, K. M., Agalgaonkar, A. P., \& Bouzerdoum, A. (2018). Customer reward-based demand response program to improve demand elasticity and minimise financial risk during price spikes. IET Generation, Transmission \& Distribution, 12(15), 3764-3771. https://doi.org/10.1049/iet-gtd.2017.2037

Wang, Z., Singh, S. N., Li, Y. J., Mishra, S., Ambrose, M., \& Biernat, M. (2017). Effects of employees' positive affective displays on customer loyalty intentions: An emotions-as-social-information perspective. Academy of Management Journal, 60(1), 109-129. https://doi.org/10.5465/amj.2014.0367

Wu, C. W. (2016). Destination loyalty modeling of the global tourism. Journal of Business Research, 69(6), 2213-2219. https://doi.org/10.1016/j.jbusres.2015.12.032

Xenikou, A. (2017). Transformational leadership, transactional contingent reward, and organizational identification: The mediating effect of perceived innovation and goal culture orientations. Frontiers in Psychology, 8, 1754. https://doi.org/10.3389/fpsyg.2017.01754

Xiang, L., Zheng, X., Lee, M. K., \& Zhao, D. (2016). Exploring consumers' impulse buying behavior on social commerce platform: The role of parasocial interaction. International Journal of Information Management, 36(3), 333-347. https://doi.org/10.1016/j.ijinfomgt.2015.11.002

Yang, Y., Mao, Z., \& Tang, J. (2018). Understanding guest satisfaction with urban hotel location. Journal of Travel Research, 57(2), 243-259. https://doi.org/10.1177/0047287517691153 
Mones, J., \& Borbon, N. M. D.

90 Consortia Academia Publishing (A Partner of Tourism Educators and Movers of the Philippines) 